\title{
円すい状光点走查による空間姿勢検知*
}

\author{
内山寛信*1, 田中輝夫*1 \\ 倉 田純 一*1, 本多陽 介*2

\section{Method of Detecting Spatial Posture by Using Conical Optical Scanning System}

\author{
Hironobu UCHIYAMA, Teruo TANAKA, \\ Junichi KURATA and Yosuke HONDA
}

\begin{abstract}
An optical sensor system composed of a single photodetector and a laser scanning system with on algorithm to calculate the posture are proposed. The principle of this sensor is to observe the distortion of the circular trajectory of laser on the measured plane, and it is possible to obtain the information on the spatial posture based on the fundamental coordinate of the sensor. This information is calculated by using a new integrating method of the trajectory signals, and it matches well with the manipulating signal of a robot with the function of a path control. Basic experiments to verify this sensor were conducted and the validity of this sensor and algorithm was confirmed.
\end{abstract}

Key Words: Measurment, Optical Engineering, 3-D Shape Measurment, Posture Control

\section{1.はじめに}

近年, 多くの生産加エシステムは, 組立, 調整作業, などをロボットにより自動化する無人加工化が進めら れている。この作業用ロボットに自律的な作業の遂行 機能を実現(1)するため, 非接触で高速, かつ, 高精度 に姿勢情報を抽出し，空間的位置・姿勢制御を可能と

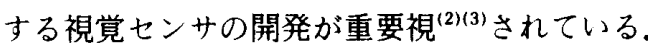

作業対象面と作業機械自身との相対的な位置, 姿勢 を計測するため，三次元空間情報を二次元画像情報よ り抽出する手法については, 多くの研究, 提案 ${ }^{(4)}$ がな されている．画像情報は，測定対象物面上の光学的特 徵点を利用する受動的な手法 ${ }^{(5)}$, あるいは, 特定の光 学的パターンを測定対象物面に照射し，その反射光を 検出する能動的な手法により取得される。能動的な点, 線状パターン照射法は, 光点像を検出して 3 角測量法 により多数点の距離情報を算出後，これらの情報を総 合化して空間的な位置, 形状を高精度に計湘できる特 徵(6)をもつ。この手法に比べて，円すい状光を用いて， 測定対象物面上に環状のパターンを照射する手法は,

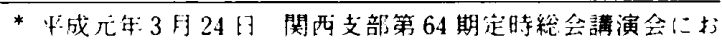
: 二劃演。原稿受付 平成元年 9 月 11 日

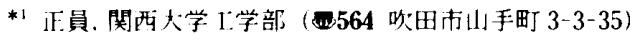

*2関西大学大学院(現在. マツ夕゙(㧣)勤務)
着目する測定部の局所的な位置，姿勢情報を短時間に 精度良く取得できるため, 走査性と姿勢検出の高速化 などの点で，ロボット系センサに有効な手法(7)であ る.

円すい状光照射法を用いたロボット用センサには， パルス状の逐次点光走査により, 投光点像の軌跡径変 化と回転方向により焦点からの遠近識別をするセンサ の研究 ${ }^{(8)}$. 環状光投射法によるパターンのスポット状 態変化による距離測定，面素の外周部を走査し，その 検出光量変化を用いた傾斜状態検出 ${ }^{(9)}$ ，ならびに，環 状光走査による三次元物体の特徴抽出の研究 ${ }^{(10)}$ がな されている。

本研究においては，着目する測定部の局所的な情報 より，センサ系のもつ基準座標軸に対する測定対象物 面の位置と空間姿勢の情報を, 独立した多数点距離情 報の取得走査を行うことなく検知する手法について提 案する。

空間姿势は，円すい状の連続した光線走査により， 測定対象物面上に照射された低円側の円状光点軌跡の 変形量より検知する. 円状光点軌跡の変形量は, 両軸 の位置信号が独立して出力される二次元光点位置検出 素子の出力信号の積分値から求める。この際，積分は 光点軌跡の全周について行われる。そして, 両軸信号 
の积分值より，着目する測定対象面部の空間姿势を， センサ系の基準座標軸からの並進移動量と他の 2 軸回 りの回転角として算出する.これらの光点走查法と信 号処理法により, 演算処理時間の短縮化, 空間的な位 置・姿势情報の精度の向上, 光学的・電気的雑音による 測定誤差の低減化などを計っている。

以下においては, 円すい状光点走査機桡をもつ位 置・姿势検知用の単眼式近接センサについて, 測定原 理と信号処理法，および，試作装䡒を用いた有効性の 検証結果を報告する。

\section{2. 空间姿势センサの權成}

$2 \cdot 1$ センサ系の楼成要脊 円すい状光点走查に よる位置・姿势検知用の単眼式近接センサの構成説明 図を図 1 に示す。センサ系の主たる構成要素は, 半笽 体レーザ光源：a，测定対象物面上に照射する光点像 の走査機構要素である車磁式走査ミラー：b，および, 光点像の撮像要素としての半導体位直検出素子 (PSD) カメラ：cである。検証実験用の試作装置では, 波長 が $830 \mathrm{~nm}$, 出力が $30 \mathrm{~mW}$ の光源と, 最大位置検出誤 差が $\pm 250 \mu \mathrm{m}$ である PSD 素子を用いている。また， 増幅器を含む電磁式走查ミラーの特性は, 感度一様な 最大周波数が $10 \mathrm{~Hz}$ である.

レーザ光は, 直交する 2 軸の電磁式走查ミラーによ り円すい状に走查され，ハーフミラー：dを介し, 測 定対象物面：e上に連続した円状の光点像軌跡を描 く.測定対象物面上の光点像は, ハーフミラー,レンズ 系を介し半導体位置検出素子で模出され，直交する 2 朝の位置信号に変換, 出力される.

$2 \cdot 2$ 基泍座栖系と光点像轨跡 センサ系の基準 坐標軸は,レンズ中心位置 $\mathrm{O}_{0}$ を原点とする図 2 に示 す $X_{0}-Y_{0}-Z_{0}$ 直角座標系であり，七ンサ系のレンズ光 軸は $Y_{0}$ 軸と一致する.測定対象物面は， $X_{0}, Y_{0}$ 軸回り にそれぞれ角度 $\alpha, \beta$ 回転し, 原点より距離 $L$ 並進移
動した $X_{3}-Y_{3}-Z_{3}$ 座標系の $X_{3}-Z_{3}$ 軸面で構成される $P_{1}$ 面である。ここで，空間姿朔情報として測定すべき 物理量は，原点であるレンズ心位置と測定対象物面 間のレンズ光軸上の距離 $L$,ならびに，センサ系の基 準座標軸に対する測定対象物面の回転角 $\alpha, \beta$ である. $\mathrm{P}_{1}$ 面上の $p_{1}\left(x_{3}, 0, z_{3}\right)$ 点は，次式により基準座標軸 系の位置 $p_{1}\left(x_{0}, y_{0}, z_{0}\right)$ に変換(11)される.

$\left[x_{0}, y_{0}, z_{0}, 1\right]^{T}=T\left[x_{3}, 0, z_{3}, 1\right]^{T}$

たたし，変換行列は次式で与えられる。

$$
T=\left[\begin{array}{cccc}
\cos \beta & -\cos \alpha \sin \beta & \sin \alpha \sin \beta & 0 \\
\sin \beta & \cos \alpha \cos \beta & -\sin \alpha \cos \beta & L \\
0 & \sin \alpha & \cos \alpha & 0 \\
0 & 0 & 0 & 1
\end{array}\right]
$$

電磁式走查ミラー機構 : $\mathrm{b}$ とハーフミラー： $\mathrm{d}$ を介 して照射される光点の回転中心位置を，基準座標系の $Y_{0}$ 軸上の位置に変換すれば, 光は座標原点 $\mathrm{O}_{0}$ から $l_{1}$ 離れた $O_{1}\left(0, l_{1}, 0\right)$ 点から出射する. そして, 光点は $Y_{0}$

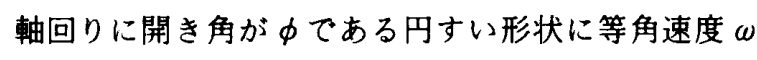
で走査される、 $Y_{0}$ 軸を法線とし，原点 $\mathrm{O}_{0}$ から $l_{4}$ の位

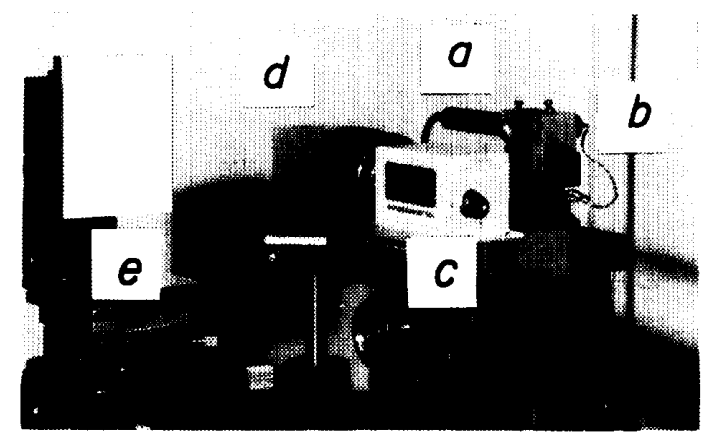

図 1 円すい走查機構をもつ姿聟検出装置 ( $\mathrm{a} ：$ 半算体レーザ, $\mathrm{b} ：$ 電磁式走査ミラー, $\mathrm{c}:$ : カラ, d : ハーフミラー, e : 測定対象物面)

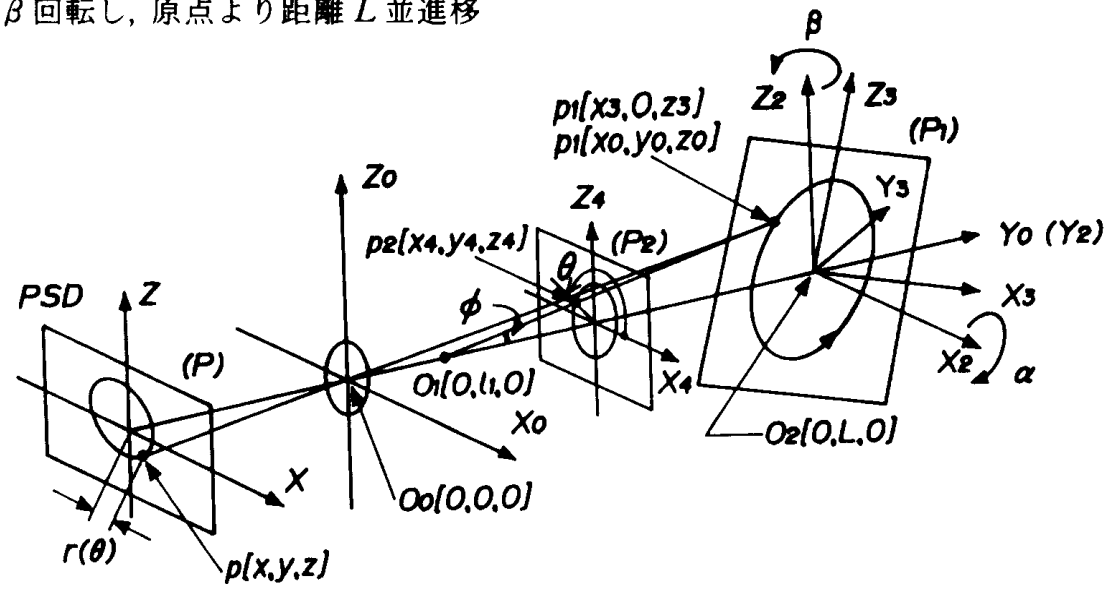

図 2 検出機構の座標系 
置にある $\mathrm{P}_{2}$ 平面上の走查光点像 $p_{2}\left(x_{4}, y_{4}, z_{4}\right)$ の基準 座標系での位置 $p_{2}\left(x_{0}{ }^{\prime}, y_{0}^{\prime}, z_{0}{ }^{\prime}\right)$ は次式となる。

$$
\left.\begin{array}{l}
x_{0}{ }^{\prime}=\left(l_{4}-l_{1}\right) \tan \phi \cos \theta \\
y_{0}{ }^{\prime}=l_{4} \\
z_{0}{ }^{\prime}=\left(l_{4}-l_{1}\right) \tan \phi \sin \theta
\end{array}\right\}
$$

$\mathrm{P}_{2}$ 面を $Y_{0}$ 軸方向に並進移動すれば, 光点像の位置 は測定対象物面である $P_{1}$ 面上の $p_{1}$ 点に一致し，その 位置座標は $\left(x_{0}, y_{0}, z_{0}\right)=\left(x_{0}^{\prime}, y_{0}^{\prime}, z_{0}^{\prime}\right)$ なる条件を満足 する.そして，この光点像は，原点 $\mathrm{O}_{0}$ からl後方にあ る PSD 撮像素子面上の点 $p(x, y, z)$ に結像する。これ らの関係を式(1)〜（３）を用いて整理すれば，撮像素 子の出力信号は, 次式で与えられる.

$$
\left.\begin{array}{l}
x(\theta)=r(\theta) \cos \theta \\
z(\theta)=r(\theta) \sin \theta
\end{array}\right\}
$$

ただし，撮像素子面上の結像軌跡の動半径は，式 (5) で与えられ，特に，測定対象物面が $Y_{0}$ 軸を法線とす る場合には，式(6)となる。

$$
\begin{aligned}
& r(\theta)=-l\left(L-l_{1}\right) \tan \phi \cos \alpha \cos \beta l \\
& \left\{L \cos \alpha \cos \beta-l_{1} \tan \phi(\cos \alpha \sin \beta \cos \theta\right. \\
& -\sin \alpha \sin \theta)\} \\
& r_{0}=[r(\theta)]_{\alpha=0, \beta=0} \\
& =-\frac{l\left(L-l_{1}\right)}{L} \tan \phi
\end{aligned}
$$

走査光点像の撮像素子面上での結像軌跡と, 撮像素 子の出力信号 $x(\theta), z(\theta)$ の一例を図 3,4 に示寸.

図 2 の光学系において, 光源位置が $l_{1}<0$ で, 測定 対象物面が $Y_{0}$ 軸を法線とする場合には, 測定面の $Y_{0}$ 軸方向距離の减少に伴い，センサ光軸点を原点とした 結像軌跡半径 $r_{0}$ は滑らかに増大する。そして, 余弦・ 正弦波形となる撮像素子出力信号 $x(\theta), z(\theta)$ の振幅 が増大する. $l_{1}>0$ の場合には, 前挙動とは逆に, 結像 軌跡半径と撮像素子信号振幅は隇少する. $l_{1}=0$ の場合 には，両者は一定値を保持し，測定系として無効とな る.試作装置の光学系パラメー夕は, 光源位置 $l_{1}=$ $-72.8 \mathrm{~mm}$, 撮像素子位置 $l=58.9 \mathrm{~mm}$, 開き角 $\phi=$ $3.03^{\circ}$ である。

測定対象物面が傾斜している場合には，軌跡半径は 動半径 $r(\theta)$ となり，撮像素子出力信号 $x(\theta), z(\theta)$ は ひずみをもつ余弦・正弦波状信号となる．信号 $x(\theta)$, $z(\theta)$ が極值をもつ走查回転角 $\theta_{x}, \theta_{z}$ は, 測定対象物 面の回転角 $\alpha, \beta$ に依存して変化し, 式(4)，（5)より 次式で示される。

$$
\begin{aligned}
& \theta_{x}=\sin ^{-1}\left(-\frac{l_{1}}{L \cos \beta} \tan \phi \tan \alpha\right) \\
& \theta_{z}=\cos ^{-1}\left(\frac{l_{1}}{L} \tan \phi \tan \beta\right) \cdots \cdots \cdots \cdots
\end{aligned}
$$

\section{3. 位置・姿整情報の演算原理}

$3 \cdot 1$ 距離 $L$ の测定手法 測定対象点の位置は， 原点からのセンサ光軸上の距離 $L$ として測定される. 距離 $L$ を測定するため, 掫像素子の出力信号 $x(\theta)$, $z(\theta)$ を用い, 湘定対象物面の傾斜角 $\alpha, \beta$ と動半径 $r(\theta)$ の関係を定量的に解析する. 光点走查 1 サイクル 当たりの動半径の変化量の平均值を, 面法線が $Y_{0}$ 軸 である測定面信号で無次元化した次式で定義する.

$$
A_{x}=\frac{S_{x}-S}{S}, A_{z}=\frac{S_{z}-S}{S}
$$

ただし，各項は次式で示される。

$$
\begin{aligned}
& S_{x}=\int_{0}^{2 \pi}|r(\theta) \cos \theta| d \theta=\int_{0}^{2 \pi}|x(\theta)| d \theta \\
& S_{z}=\int_{0}^{2 \pi}|r(\theta) \sin \theta| d \theta=\int_{0}^{2 \pi}|z(\theta)| d \theta \\
& S=r_{0} \int_{0}^{2 \pi} \mid \sin \theta \text { or } \cos \theta \mid d \theta,(\theta=\omega t)
\end{aligned}
$$

式 (9)内の超越関数の積行を数值計算により求め, 図 5 に示す。この特性図，および, 計算結果より，測定 距離 $L$ を一定とした場合には，測定対象物面の傾斜

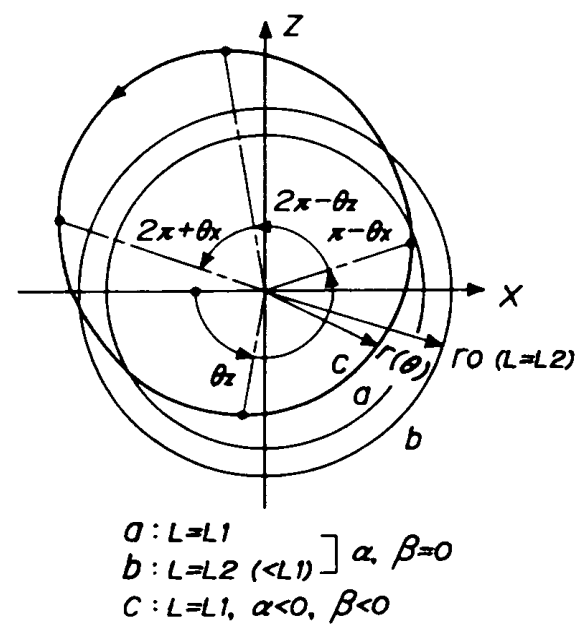

図 3 走查光点像の結像軌跡
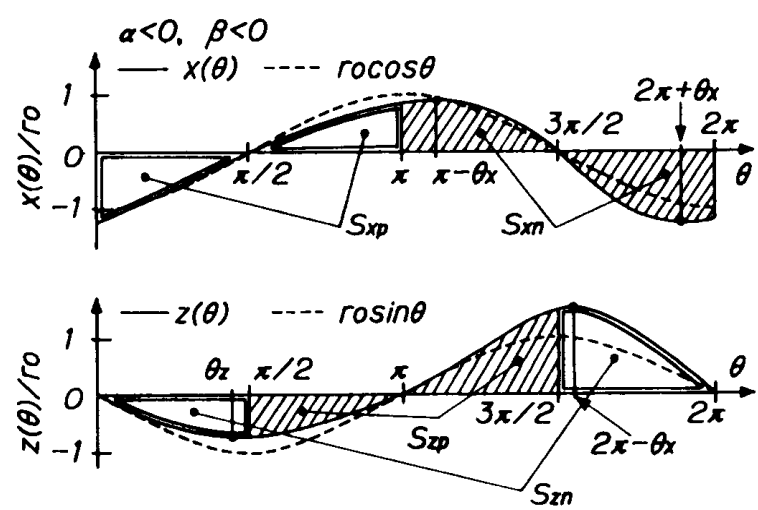

図 4 撮像素子の出力信号 
角 $\alpha, \beta$ による動半径 $r(\theta)$ の変動量は小さく, 1 サ1 クル走查間の信号波形の積分值は，変動が極めて小さ

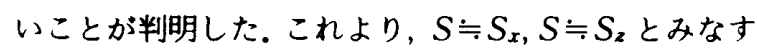
ことが可能であり, 光点走查 1 サイクル間の動半径 $r(\theta)$ の平均値は， $r_{0}$ で精度良く近似できる。

$Y_{0}$ 軸上を測定対象物面が遠点に並進移動した場合， 円すい状走査の効果により，撮像素子面上の結像点軌 跡の半径は距離 $L$ にほほ反比例して減少する。また， $S_{x}, S_{z}$ は $S$ に比例する。これらの関係より, 距離 $L_{m}$ は次式により算出できる。

$$
\begin{aligned}
L_{m} & =\frac{4 l l_{1} \cdot \tan \phi}{4 l \tan \phi-S_{x}} \text { or } \frac{4 l l_{1} \cdot \tan \phi}{4 l \tan \phi-S_{z}} \\
& \fallingdotseq L
\end{aligned}
$$

式(10)による距離演算の測定誤差を $\left(L_{m}-L\right) / L て ゙$ 評価したものが図6である。これより，良好な測定精 度が得られることがわかる。

光点走查 1 サイクル間の撮像素子出力信号波形を積 分した面樻量より距倠 $L$ を算出する手法は，測定対 象物の微細な面棈造による反射光路の変動, ならびに, 光強度の変動, 外部環境光の強度変動, などの光学的 雑音, 電気的雑音による誤差の低隇化を計るために極 めて有効である。また， 3 角測量法により多数点の距 離測定をした後、それらの情報を総合化, 平均值化し て距離を求める手法に比べ，演算の高速化と回路系の 簡略化が望める。

$3 \cdot 2$ 測定対象物面の倾斜角の測定手法 $3 \cdot 1$ 節 で求めた距離情報 $L_{m}$ を用いれば，式（7），（8）の関 係より，測定対象物面の傾斜角である $X_{0}, Y_{0}$ 軸回り の回転角 $\alpha, \beta$ が算出できる.しかし， $x(\theta), z(\theta)$ 信号 の極値を微分操作により求め, $\theta_{x}, \theta_{z}$ を算出する手法 は，信号中の雑音により大きな誤差が発生すると推測 される。式(4)〜 (8)ならびに図 4 から, $x(\theta), z(\theta)$

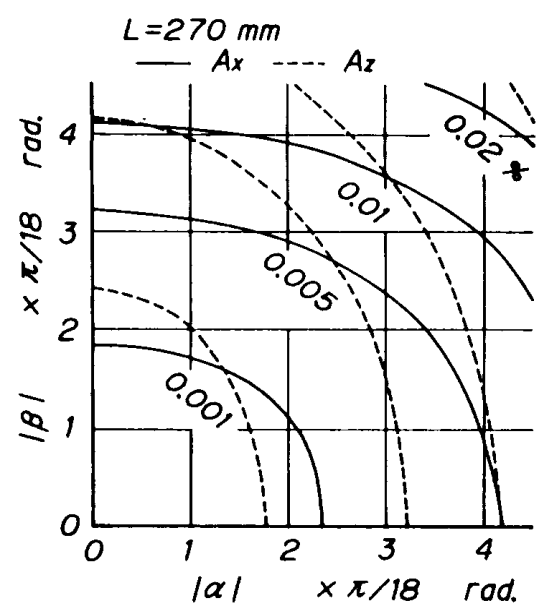

図 5 位置信号の面樌量の変化状態
信号が極值をとる走查回転角は, $r_{0} \cos \theta, r_{0} \sin \theta$ 波 形の極值近傍にあり, $L, \alpha, \beta$ による変化量が小さい ことがわかる.そこで, $x(\theta), z(\theta)$ 信号の複振幅, なら びに, 光点走查 1 サイクル間の信号波形の面䅡量が, 測定対象物面の傾斜角 $\alpha, \beta$ の変動の影幚を受けず一 定である信号波形のひずみ特性に着目し，波形のひず み量を面積量に変換し $\theta_{x}, \theta_{2}$ の移動量を算出する手法 について検討をする。

$\theta_{x}, \theta_{z}$ の変動に伴う信号波形のひずみ量を表示する 面積量として, 次式を定義する (図 4 参照).

$$
\begin{aligned}
& R_{z}=\frac{\Delta S_{z}}{S_{z}}, \Delta S_{z}=S_{z 1}-S_{z 2} \\
& R_{x}=\frac{\Delta S_{x}}{S_{x}}, \Delta S_{x}=S_{x 1}-S_{x 2}
\end{aligned}
$$

ただし，

$$
\begin{aligned}
& S_{z 1}=\int_{0}^{\pi / 2}|z(\theta)| d \theta+\int_{3 \pi / 2}^{2 \pi}|z(\theta)| d \theta \\
& S_{z 2}=\int_{\pi / 2}^{3 \pi / 2}|z(\theta)| d \theta \\
& S_{x 1}=\int_{0}^{\pi}|x(\theta)| d \theta, S_{x 2}=\int_{\pi}^{2 \pi}|x(\theta)| d \theta
\end{aligned}
$$

式(11)に示す信号波形の面積量の比 $R_{z}$ は、式(8) で与えら的る極值の移動量 $\theta_{z}=f_{z 0}(1 / L, \tan \beta)$ に依存 して変化すると考えら机る。ここで， $R_{2}$ と $\tan \beta$ の関 係を $L, \alpha$ をパラメータとして数值計算し図 7 に示す。 計算結果より， $|\alpha, \beta|<\pi / 4$ ラジアンの条件下では， $\alpha$ に対する $R_{z}$ の変動は極めて小さく無視することが可 能である， $R_{2}$ の変動量を， $\alpha=0$ の場合を代表值にし て他者と比較すると， $\beta \neq 0$ では，最大変動量は 0.05 \%以下である。また， $L$ の増加に伴い，直線こう配は 滅少する。これより， $R_{z}=f_{z}(1 / L, \tan \beta)$ なる $\alpha$ に依存 しない関数関係を仮定できる。この仮定に基づき， $\theta_{\boldsymbol{z}}$ $=\cos ^{-1} R_{z}$ より，新たな綐軸 $\cos \theta_{z}$ と $\tan \beta$ との特性 図を得る.図 7 より, 次式に示す関係式が求められる。

$2 R_{z}=\cos \theta_{z}$

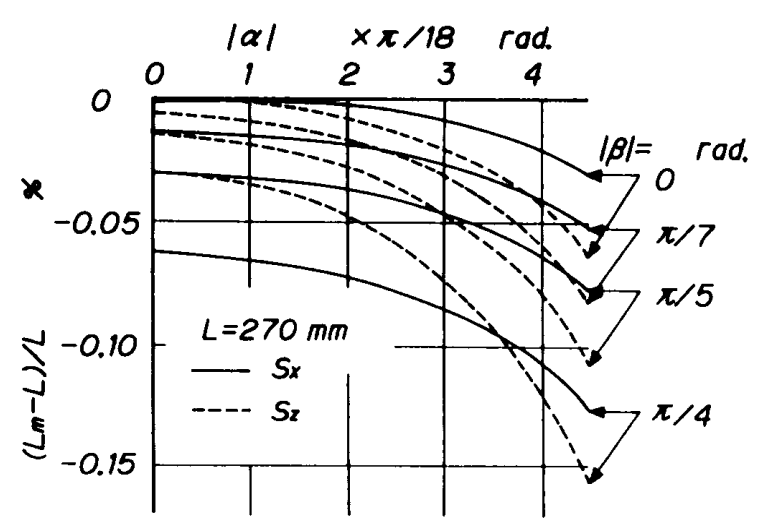

図 6 距峌測定アルゴリスムの誤差解析 


$$
=\frac{C \tan \beta}{L}
$$

ただし，

$C=l_{1} \tan \phi$

距離情報 $L$ は $L_{m}$ に置換でき, $\beta$ は式(13)より求ま る.

$$
\beta=\tan ^{-1}\left(\frac{2 R_{z} \cdot L_{m}}{C}\right)
$$

式(12)についても同様な条件下で数值計算と処理を すると, 面積量の比 $R_{x}$ は式 $(7)$ 右辺の括弧内と同様 な関数関係 $R_{x}=f_{x}(1 / L, 1 / \cos \beta, \tan \alpha)$ を満足する. 数值計算結果を図 8 に示す. $\beta, L$ によって変化する特 性線図のこう配は一定であり，次式の関係で表示でき る.

$$
\begin{aligned}
2 R_{x} & =\sin \theta_{x} \\
& =-\frac{C \tan \alpha}{L} \cos \beta \ldots \ldots \ldots \ldots . . . \\
\therefore \alpha & =\tan ^{-1}\left(-\frac{2 R_{x} \cdot L \cos \beta}{C}\right)
\end{aligned}
$$

式(13)，(15)より， $R_{z} \neq 0(\beta \neq 0)$ の場合には，次式が 成立する。

$$
R_{x z}=\frac{R_{x}}{R_{z}}=-\frac{\tan \alpha}{\sin \beta}
$$

これより， $\alpha$ は次式で示される。

$$
\alpha=\tan ^{-1}\left(-R_{x z} \cdot \sin \beta\right)
$$

なお，数值解析結果によれば, $R_{x} / R_{z} \fallingdotseq \Delta S_{x} / \Delta S_{z}$ と近 似しても充分な精度が得られる。

以上のことより，測定対象物面の傾斜角と撮像素子 信号波形の面積量との関係を定式化でき，距雔 $L$ の 算出手法上同様に簡単なアルゴリズムで測定対象物面 の傾斜角の算出が可能となる。

\section{4. 信号処理回路系の㩐成}

提案したように，センサ系の姿勢情報である距離, 基準座標軸回りの回転角である $L_{m}, \alpha, \beta$ は，光学的， 電気的雑音による測定誤差の低減化が可能な積分演算 処理法により算出される。しかし，信号量が小さいた め, 安定性, 分解能の良好な積分器を使用することが 望ましい。

検証実験用に試作した装置の信号処理回路系と，姿 勢情報の演算処理過程のブロック図を図 9 に示す。

半導体位置検出素子の位置信号 $x(\theta), z(\theta)$ は，絶対 值回路を介し高精度・高パルス密度の電圧・周波数変 換器 $(0.5 \mathrm{Mpulse} / \mathrm{V})$ でパルス列信号に変換される. そのパルス列信号はカウンタで加算積分され，信号波 形の面積量に変換される，そのとき，積分範囲は光点 走查信号に同期して制御される。
面穔量である樻分值は，マイクロプロセッサにより 処理され，数值化された姿勢情報として出力される. 最初に, $x(\theta)$ あるいは $Z(\theta)$ 信号の面程量 $S\left(\fallingdotseq S_{x}\right.$, $\left.\fallingdotseq S_{z}\right)$ より距離 $L_{m}$ を算出し，ついで， $R_{z}$ と $L_{m} よ り$ $\beta$ を求め，その後， $R_{x z}, \beta$ より $\alpha$ を算出する.この際, $\Delta S_{z}=0$ である $\beta=0$ の場合には， $R_{x}$ より $\alpha$ を算出す る.

\section{5. 試作䕭買による測定桔果}

図 1 ならびに図 9 に示す試作した測定系を用い，測 定原理を実験的に検証した結果を以下に示す。

図 10 が距離測定の結果であり，基準座標軸に対す る測定対象物面の回転角が $\pi / 6$ ラジアン以内におい ては，良好に測定できることが判明した。測定精度は， 試作装置の測定距離範囲内においては， $\pm 1 \mathrm{~mm}$ 程度 である。

測定対象物面の回転角 $\beta$ を，式(14)を用いて算出し た実測值を先の図 7 にプロットして示す。ただし，実 測值は $|\alpha|<\pi / 6$ ラジアンの場合である.同様に，回転

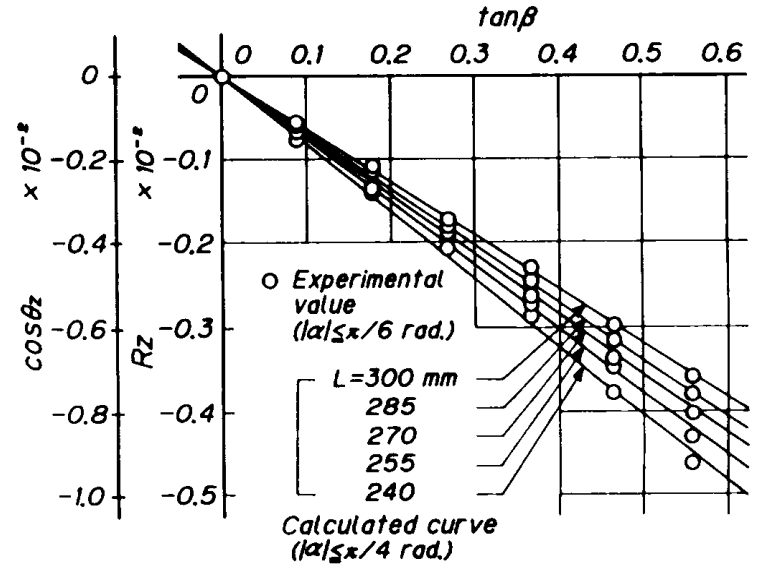

図 7 極値をとる走査回転角と面䅡量の関係

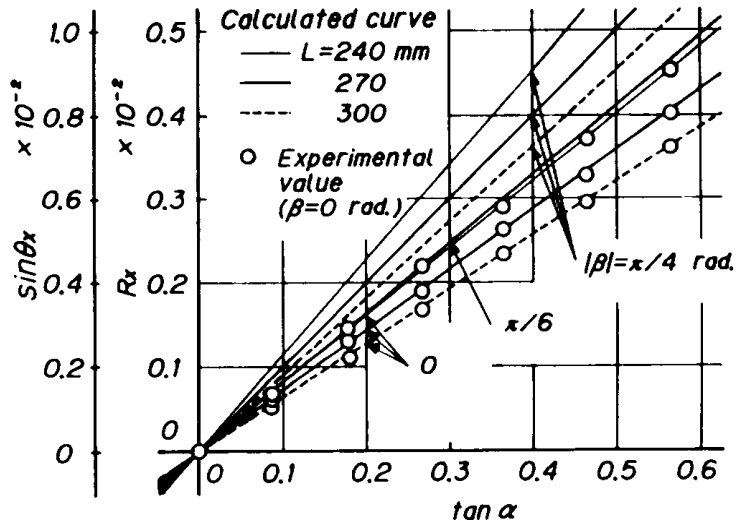

図 8 面樌量と $\alpha$ との関係図 
角 $\alpha$ の算出結果は, 図 8 に $\beta=0$ の代表例についてプ ロットして示す。

図 7，8より, 面䅡量とその比から測定対象物面の 傾斜角を算出する式(11) （17)の闍係式の妥当性が確 認される。

総合的な測定対象物面の基鈄座標軸に対する回転角 $\alpha, \beta$ の測定結果は，それぞれの回転角が $\pi / 6$ ラジアン 以内の場合について，図11(a)，(b)に示す。両側定 結果より，回転角による姿势测定の精度は，ほほ $\pm 1^{\circ}$ である。

測定アルゴリスムなどの検証用試作装罳の場合にお いては, 距離, 回転角の測定誤差は, 光学装置系に多 数存在する位置調整用可動部の設定の困㩲さによるも のであり，小形，一本化し刚性を高め固定化すれば, さらに良好な測定精度を得られると考える。

\section{6. ま と め}

円すい状の光点走查による測定対象物面上の結像点
軌跡の変形量より，空間的な位目・姿势を模知する視 賞センサ系とその演算アルコリスムを提案し，試作測 定装置を用い検証した。

その結果, 円すい状に走查された測定対象物面上の 円状光点像の軌跡は,

（1）測定対象物面までの距踓により，センサ光軸 を原点とする平均動半径が変化する。しかし, 半径変 化に対する，測定対象物面の傾斜角の影管は微小であ る.

（2）測定対象物面が傾斜することにより，軌跡の 長軸と短軸位置が回転移動する。

この両者の性質を用い, 二次元撮像素子の 2 軸位嘈信 号波形の面積量ならびにその比から，測定対象物面の 姿势を，センサ系のもつ基準座標軸からの距離，なら びに，軸系に対する回転角として算出するアルゴリス ムを数值解析的に導き，提案した。

数值解析および試作装置による検証実䜿の結果, 以 下のことが判明した。

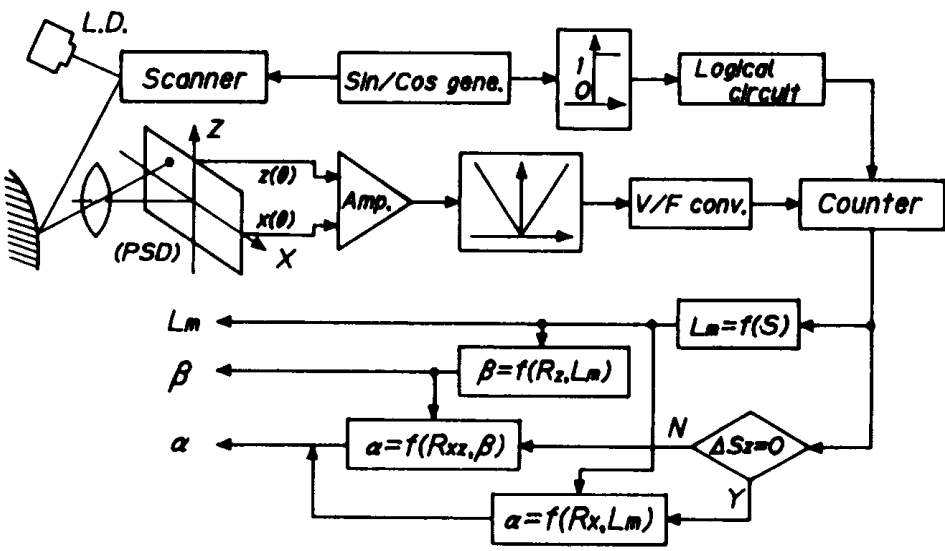

図 9 信号処理回路系のフロック図

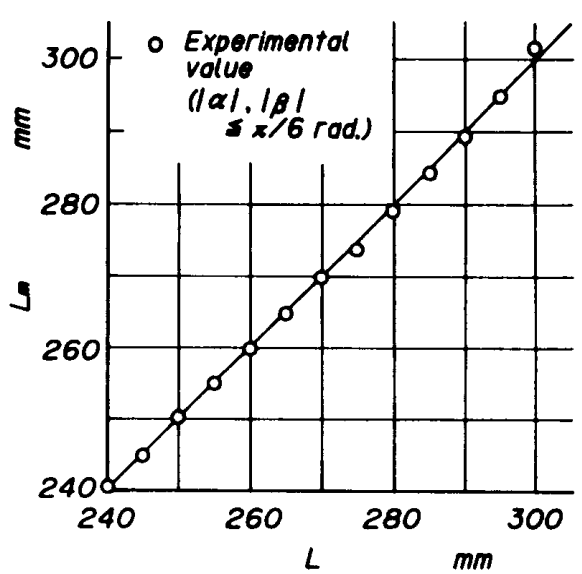

図 10 距離剆定の結果

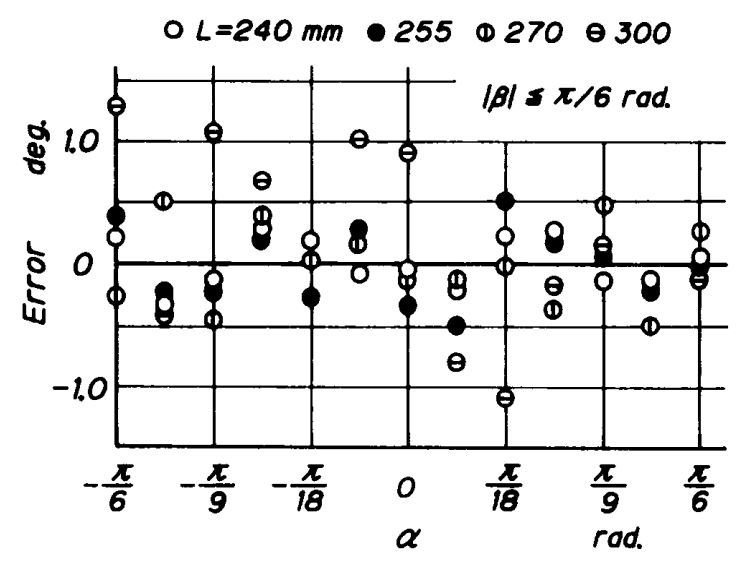

(a)〔日転角 $\alpha$ U测定

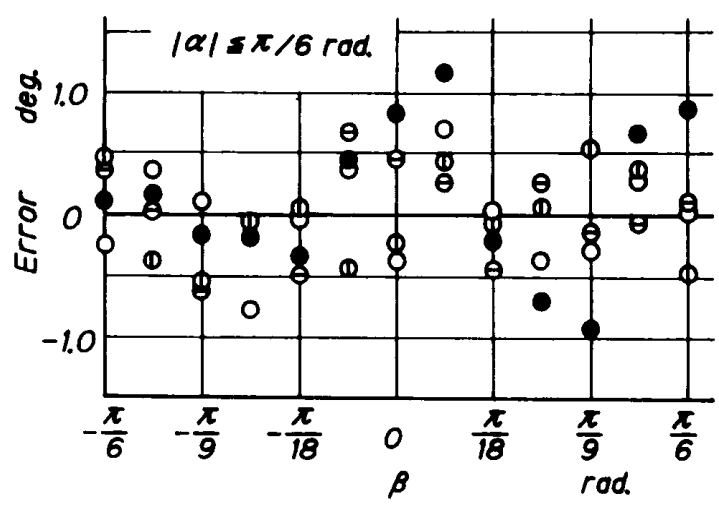

(b) 回転角 $\beta$ の測定

図 11 傾斜角の測定結果 
（1）简単な情報処理を施すことにより, 距離, 回 転傾斜角の姿势情報が直接的に算出できる。

（2）検証実験の結果，距離および回転角の測定精

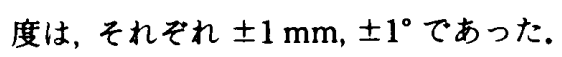

光学系を軽量化して㣚性を強化し，一体化すればさ らに測定精度の向上が望め, 小形な単眼視覚センサと して有効であると考える。

\section{文献}

（1）金出、日本ロポット学会誌, 5-5(1987)、376.
（2）石井・はか2 名. 計自論. 21-4(1985)，403.

(3) 出澤。計測々制御, 26-2(1987). 103.

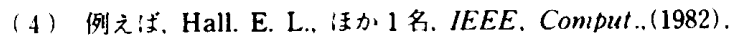
42.

（5）例之活，安江・白井，電絰研究報，37-12(1974)，1101.

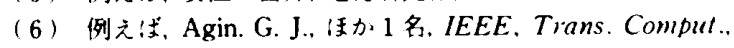
$25 \mathrm{C}-4(1976), 439$.

(7) 标下・出澤、計自論, 22-11, (1986)， 1204.

（8）花房・活力２名。第 27 回 JAACE 諈論集。 (1983)，117.

(9) 木下・出䐾, 電学論, 107-5(1987), 436.

(10）朴・出澤, 計自論, 25-1(1989). 112.

(11) Paul, R. P.. Robot Manipulators. (1981), 13. M. I. T. Press. 